University of Nebraska - Lincoln

DigitalCommons@University of Nebraska - Lincoln

\title{
Alternative Heifer Development Systems Utilizing Corn Residue and Cover Crops
}

Hannah F. Speer

Hannah E. Riley

R. A. Cushman

Harvey C. Freetly

M. E. Drewnoski

Follow this and additional works at: https://digitalcommons.unl.edu/animalscinbcr

Part of the Large or Food Animal and Equine Medicine Commons, Meat Science Commons, and the Veterinary Preventive Medicine, Epidemiology, and Public Health Commons

This Article is brought to you for free and open access by the Animal Science Department at DigitalCommons@University of Nebraska - Lincoln. It has been accepted for inclusion in Nebraska Beef Cattle Reports by an authorized administrator of DigitalCommons@University of Nebraska - Lincoln. 


\section{Alternative Heifer Development Systems Utilizing Corn Residue and Cover Crops}

\author{
Hannah F. Speer \\ Hannah E. Riley \\ Robert A. Cushman \\ Harvey C. Freetly \\ Mary E. Drewnoski
}

\section{Summary with Implications}

Growth and reproductive performance of heifers developed in 3 different winter systems to target a common body weight by 10.5 months of age was evaluated. Systems were corn residue grazing supplemented with dried distillers grains, corn residue supplemented with wheat midds, or cover crop followed by corn residue grazing supplemented with dried distillers grains. Heifers were on their respective treatment from 7 to 10.5 months of age (approximately 98 days) and then comingled and fed a common diet. Overall gains were greatest for heifers grazing cover crops compared to heifers on corn residue treatments. Prebreeding body weight was 20 pounds greater for heifers grazing cover crops compared to other treatments. Pregnancy rates were greater for heifers on cover crop (75.4\%) compared to heifers supplemented with wheat midds (64.3\%), while heifers supplemented dried distillers grains (69.5\%), were intermediate not differing from cover crop or wheat midds. These data suggest that plane of nutrition during the development period may have affected fertility. Utilizing oat-brassica cover crop grazing during early winter to achieve a high rate of gain followed by corn residue grazing with dried distillers grains supplementation to target a lower rate of gain could be effective for developing beef heifers.

\section{Introduction}

Plane of nutrition at certain times during development may affect oocyte quality as well as attainment of puberty. In particular, a nutritional challenge may

(c) The Board Regents of the University of Nebraska. All rights reserved.

Table 1. Supplement intakes of heifers during mid-November to mid-January (Phase 1) and midJanuary to late February (Phase 2) of the winter grazing period.

\begin{tabular}{lccc}
\hline & \multicolumn{3}{c}{ Treatment $^{1}$} \\
\cline { 2 - 4 } & CD & CW & CC \\
\hline Supplement DM intake, lb/hd/d & & & \\
Phase $1^{2}$ & 1.61 & 3.57 & - \\
Phase $2^{3}$ & 2.16 & 4.32 & 0.76 \\
\hline
\end{tabular}

${ }^{1}$ Grazing treatments: corn residue with DDGS supplementation (CD); corn residue with wheat midds supplementation (CW); late summer planted cover crop followed by corn residue with DDGS supplementation (CC).

${ }^{2}$ Heifers 9 months of age at the end of phase.

${ }^{3}$ Heifers 10.5 months of age at the end of phase.

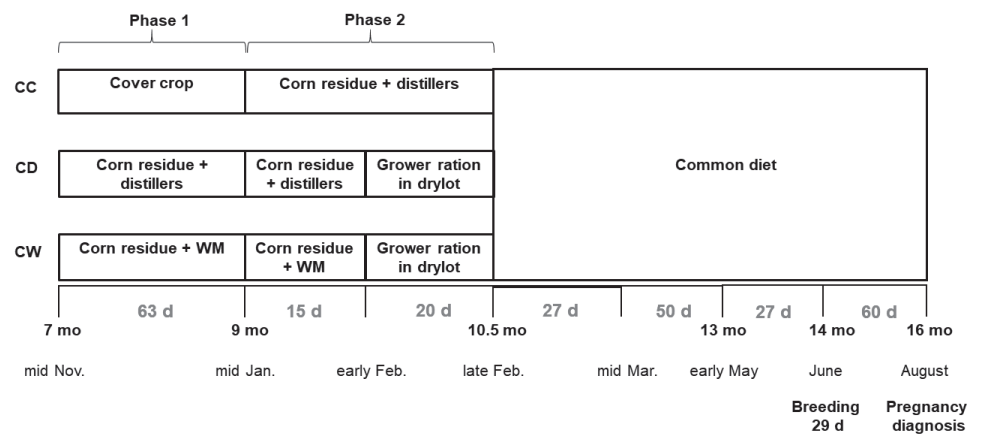

Figure 1. Experimental timeline and illustration of dietary treatments of winter heifer development systems, with heifer age indicated at hash marks. Heifers were assigned to either graze cover crop followed by corn residue grazing (CC) or graze corn residue while receiving protein supplementation as either dried distillers grains (CD) or wheat midds (CW). At the end of Phase 1, CC heifers were placed on corn residue and received a DDGS supplement for the remainder of the experimental feeding period (Phase 2). In phase 2, CD and CW heifers remained on corn residue for $15 \mathrm{~d}$ before being placed in the drylot. Following Phase 2, all heifers were comingled and fed a common diet. Breeding season began in June and lasted for 29 d; pregnancy diagnosis occurred in August.

negatively impact oocyte growth, resulting in reduced fertility when oocytes are later ovulated. Corn residue grazing alongside dried distillers grains (DDGS)-based supplementation can serve as a low-cost option for wintering growing cattle and developing beef heifers. Additionally, supplementation levels of DDGS can be manipulated to target different rates of gain. Dried distillers grains with solubles is commonly supplemented in corn residue grazing systems because it serves as both a good protein and energy source. In other parts of the
Midwest, wheat midds could serve as a viable supplement option as they are a good source of protein and moderate in energy content. Grazing of late-summer planted oat-brassica cover crops can also be an effective way to winter growing cattle (2017 Nebraska Beef Cattle Report, pp. 40-42); however, this option has not yet been evaluated for heifer development. The objective of this study was to evaluate growth, development, and reproductive performance of heifers developed in 3 different winter systems targeted to result in a common BW at 10.5 months of age. 
Table 2. Dietary composition by year of grower ration fed during drylot period for heifers grazing corn residue with DDGS (CD) or wheat midds (CW) supplementation.

\begin{tabular}{lccc}
\hline & \multicolumn{3}{c}{ Year } \\
\cline { 2 - 4 } Ingredient, \% of DM & 2016 & 2017 & 2018 \\
\hline Alfalfa haylage & 46.7 & 17.5 & - \\
Earlage & 38.9 & 40.0 & - \\
Corn silage & - & 42.5 & - \\
Alfalfa hay & 14.4 & - & 74.0 \\
Alfalfa/grass hay & - & - & 26.0 \\
Corn, dry-rolled & - & - & \\
& & & 13.0 \\
Diet nutrient content, \% of DM & & & 64.5 \\
\multicolumn{1}{c}{ CP } & 15.4 & 10.3 & 73.5 \\
\hline
\end{tabular}

Table 3. Effect of winter heifer development system on bodyweight and average daily gain of heifers.

\begin{tabular}{|c|c|c|c|c|c|}
\hline \multirow[b]{2}{*}{ Item } & \multicolumn{3}{|c|}{ Treatment $^{1}$} & \multirow[b]{2}{*}{ SEM $^{2}$} & \multirow[b]{2}{*}{$P$-value } \\
\hline & $\mathrm{CC}$ & $\mathrm{CD}$ & CW & & \\
\hline Mid-November (Initial) BW, lb & 483 & 481 & 478 & 2.34 & 0.34 \\
\hline Mid-January (Mid) BW, lb ${ }^{3}$ & $589^{\mathrm{a}}$ & $562^{\mathrm{b}}$ & $547^{\mathrm{b}}$ & 5.45 & $<0.01$ \\
\hline Late-February (Final) BW, $\mathrm{lb}^{4}$ & $619^{\mathrm{a}}$ & $595^{\mathrm{b}}$ & $584^{\mathrm{b}}$ & 6.44 & $<0.01$ \\
\hline May (Prebreeding) BW, $\mathrm{lb}^{5}$ & $701^{\mathrm{a}}$ & $679^{\mathrm{b}}$ & $677^{\mathrm{b}}$ & 5.89 & $<0.01$ \\
\hline May BW, $\%$ of mature BW ${ }^{6}$ & $52^{\mathrm{a}}$ & $50^{\mathrm{b}}$ & $50^{\mathrm{b}}$ & 0.44 & $<0.01$ \\
\hline \multicolumn{6}{|l|}{$\mathrm{ADG}, \mathrm{lb} / \mathrm{d}$} \\
\hline $\begin{array}{l}\text { Mid-November to mid-January } \\
\text { (Phase 1) }\end{array}$ & $1.68^{\mathrm{a}}$ & $1.28^{\mathrm{b}}$ & $1.08^{\mathrm{b}}$ & 0.09 & $<0.01$ \\
\hline $\begin{array}{l}\text { Mid-January to late February } \\
\text { (Phase 2) }\end{array}$ & $0.79^{\mathrm{a}}$ & $0.90^{\mathrm{ab}}$ & $1.08^{\mathrm{b}}$ & 0.07 & $<0.01$ \\
\hline $\begin{array}{l}\text { Early February to late February } \\
\text { (Drylot) }^{7}\end{array}$ & - & 1.46 & 1.51 & 0.17 & 0.77 \\
\hline $\begin{array}{l}\text { Late February to May } \\
\text { (Prebreeding) }\end{array}$ & 1.01 & 1.15 & 1.17 & 0.07 & 0.10 \\
\hline $\begin{array}{l}\text { Mid-November to late February } \\
\text { (Overall) }\end{array}$ & $1.39^{\mathrm{a}}$ & $1.17^{\mathrm{b}}$ & $1.10^{\mathrm{b}}$ & 0.07 & $<0.01$ \\
\hline
\end{tabular}

a,b Means within a row lacking a common superscript differ $(P<0.05)$.

${ }^{1}$ Grazing cover crop followed by grazing corn residue with DDGS supplementation (CC); grazing corn residue with DDGS (CD) or wheat midds (CW) supplementation followed by grower ration in the drylot.

${ }^{2}$ Average SEM across all treatments.

${ }^{3} \mathrm{CC}$ to corn residue and receiving DDGS supplementation; $\mathrm{CD}$ and $\mathrm{CW}$ on corn residue receiving DDGS and wheat midds supplementation, respectively, for 15 days.

${ }^{4} \mathrm{CC}$ removed from corn residue; $\mathrm{CD}$ and $\mathrm{CW}$ removed from drylot.

${ }^{5}$ Measured $27 \mathrm{~d}$ before breeding on June 1.

${ }^{6}$ Based on herd average mature cow BW of $1350 \mathrm{lb}$.

${ }^{7} 20$ days.

\section{Procedure}

A total of 1,012 spring-born heifers were used in a 3-year study conducted from 2016 to 2018 at the U.S. Meat Animal Research Center. Heifers were weaned at $148 \pm 17 \mathrm{~d}$ of age, and each year heifers were classi- crop followed by corn residue supplemented with DDGS (CC). All heifers received a mineral supplement while on their respective grazing treatments. The cover crop was planted in August and consisted of a mixture of oats ( $84 \mathrm{lb} / \mathrm{acre}$ ), daikon radish ( $2 \mathrm{lb} / \mathrm{acre})$, and purple top turnip $(1.5 \mathrm{lb} /$ acre). Supplementation was provided 3 times weekly to achieve $45 \%$ of mature BW (607 lb) by 10.5 months of age, and heifers were targeted to achieve $55 \%$ of mature BW (744 lb) by breeding in June. Average daily supplement intakes for each treatment are listed in Table 1.

A timeline of the study is provided in Figure 1. Grazing treatments were initiated in mid-November of each year. After $63 \mathrm{~d}$ (end of Phase 1/start of Phase 2), heifers on CC treatment were moved in midJanuary to corn residue and supplemented with DDGS for the remaining $35 \mathrm{~d}$ of the winter treatment period. Heifers on $\mathrm{CD}$ and CW treatments remained on corn residue until d 78 and were subsequently moved to the drylot in early February where they received a grower ration for the last $20 \mathrm{~d}$ of the treatment period (Table 2). Relocation of $\mathrm{CD}$ and $\mathrm{CW}$ heifers to the drylot at this time occurred because weather conditions in Year 1 resulted in low corn residue availability; $\mathrm{CD}$ and CW heifers were managed as such in Year 2 and 3 to be consistent across years. Heifers in the drylot consumed $11.2 \mathrm{lb} \mathrm{DM} / \mathrm{d}$ and were targeted to gain $1.1 \mathrm{lb} / \mathrm{d}$. The treatment period ended after $98 \mathrm{~d}$ in late February (end of Phase 2) at which point all heifers were comingled and fed a common diet. Heifers (14 mo of age) were bred via natural service for a 29 -d breeding season that started in June.

Individual body weights were collected on all heifers at study initiation in midNovember (d 0), end of Phase 1 (d 63), end of Phase 2 (d 98), and the first week of May. In mid-March, heifers were ultrasounded to determine reproductive tract score (RTS). The use of RTS is a practical on-farm method to determine heifer pubertal status. Reproductive tract scoring is based on a range of 1 to 5, with 1 being an infantile tract and no palpable follicles, and 5 being a tract with a functioning corpus luteum (CL) present (i.e., heifer is cycling). In early May at 13 months of age, RTS was again evaluated, and follicle count, ovarian length and height, and uterine horn diameter was determined via ultrasound. Hip heights 
Table 4. Effect of winter heifer development systems utilizing corn residue and cover crop on reproductive measures and pregnancy rate.

\begin{tabular}{|c|c|c|c|c|c|}
\hline \multirow[b]{2}{*}{ Item } & \multicolumn{3}{|c|}{ Treatment $^{1}$} & \multirow[b]{2}{*}{ SEM $^{2}$} & \multirow[b]{2}{*}{$P$-value } \\
\hline & $\mathrm{CC}$ & $\mathrm{CD}$ & $\mathrm{CW}$ & & \\
\hline \multicolumn{6}{|l|}{ March } \\
\hline Tract score ${ }^{3}$ & $4.18^{\mathrm{a}}$ & $4.07^{\mathrm{b}}$ & $4.09^{\mathrm{b}}$ & 0.03 & 0.04 \\
\hline \multicolumn{6}{|l|}{ May } \\
\hline Tract score ${ }^{3}$ & 4.61 & 4.50 & 4.56 & 0.03 & 0.08 \\
\hline Uterine horn diameter, $\mathrm{mm}$ & 10.7 & 10.8 & 10.7 & 0.10 & 0.58 \\
\hline Total follicle count ${ }^{4}$ & 20.7 & 21.3 & 20.6 & 0.49 & 0.55 \\
\hline Average ovary length, $\mathrm{mm}$ & 24.4 & 24.4 & 24.2 & 0.21 & 0.82 \\
\hline Average ovary height, $\mathrm{mm}$ & 14.0 & 13.9 & 14.1 & 0.11 & 0.43 \\
\hline Hip height, in & 48.6 & 48.4 & 48.3 & 0.11 & 0.09 \\
\hline $\mathrm{BCS}^{5}$ & 5.4 & 5.3 & 5.3 & 0.03 & 0.10 \\
\hline \multicolumn{6}{|l|}{ August } \\
\hline Pregnancy rate, $\%$ & $75.4^{\mathrm{a}}$ & $69.5^{\mathrm{ab}}$ & $64.3^{\mathrm{b}}$ & 0.03 & 0.03 \\
\hline \multicolumn{6}{|c|}{ a,bMeans within a row lacking a common superscript differ $(P<0.05)$. } \\
\hline \multicolumn{6}{|c|}{$\begin{array}{l}{ }^{1} \text { Grazing cover crop followed by grazing corn residue with DDGS supplementation (CC); grazing corn residue with DDGS (CD) } \\
\text { or wheat midds (CW) supplementation followed by growing ration in the drylot. }\end{array}$} \\
\hline \multicolumn{6}{|l|}{${ }^{2}$ Average SEM across all treatments. } \\
\hline \multicolumn{6}{|c|}{${ }^{3}$ Reproductive tract score $(1=$ prepubertal to $5=$ pubertal $)$. } \\
\hline \multicolumn{6}{|c|}{${ }^{4}$ Sum of follicles present in left and right uterine horns. } \\
\hline${ }^{5}$ Body condition score $(1=$ emaciated to 9 & & & & & \\
\hline
\end{tabular}

and body condition scores (BCS) were also collected at this time. Heifers were rectally palpated in August to diagnosis pregnancy.

All data except for pregnancy data were analyzed using the MIXED procedure of SAS (SAS Institute, Inc., Cary, N. C.). Pregnancy data were analyzed using the GLIMMIX procedure of SAS with binomial distribution of the data. Fixed effects were treatment and year, and replicate within a year was a random effect. Kenward-Roger approximation was utilized for degrees of freedom. Significance was declared at $P \leq$ 0.05 .

\section{Results}

Heifer body weight and average daily gain

Initial (mid-November) BW did not differ among treatments $(P=0.34$; Table 3$)$. At the end of Phase 1 (mid-January), CC had a greater BW (589 lb) than CD and CW (562 and $547 \mathrm{lb}$; respectively); $\mathrm{CD}$ and CW did not differ from each other $(P<0.01)$. Final (late-February) BW was greater for CC than for CD and CW $(P<0.01)$, with $\mathrm{CC}$ being approximately $25 \mathrm{lb}$ heavier than $\mathrm{CD}$ and $35 \mathrm{lb}$ heavier than CW. In May (prebreeding), BW was 20 to $25 \mathrm{lb}$ greater for CC (701 lb) compared to CD (679 lb) or CW (677 lb; $P<0.01)$. Consequently, CC heifers achieved a greater percentage (52\%) of mature BW in May (27 d prior to the breeding season) than $\mathrm{CD}$ and $\mathrm{CW}$ heifers (50\%; $P<0.01)$.

Average daily gain during Phase 1 was greater for CC than for $\mathrm{CD}$ and $\mathrm{CW}(1.68$ vs. 1.28 and $1.08 \mathrm{lb} / \mathrm{d}$, respectively; $P<$ 0.01). In Phase 2, CW had an ADG of 0.29 $\mathrm{lb} / \mathrm{d}$ more than $\mathrm{CC}$, but ADG was not different from $\mathrm{CD}(P<0.01)$. During the $20-\mathrm{d}$ period in the drylot, ADG was not different between $\mathrm{CD}$ and $\mathrm{CW}(P=0.77)$ as both gained approximately $1.50 \mathrm{lb} / \mathrm{d}$. Average daily gain over the entire winter treatment period for CC was $0.22 \mathrm{lb} / \mathrm{d}$ greater than $\mathrm{CD}$ and $0.29 \mathrm{lb} / \mathrm{d}$ greater than $\mathrm{CW}$, whereas $\mathrm{CD}$ and $\mathrm{CW}$ did not differ from each other $(P<0.01)$.

\section{Reproductive measures}

Heifer reproductive measures are listed in Table 4. In March, CC had a greater RTS than $\mathrm{CD}$ and $\mathrm{CW}$ heifers $(P=0.04)$; however, there were no differences in RTS across treatments in May $(P=0.08)$, suggesting that all heifers were of similar reproductive maturity prior to the breeding season. Within CC, CD, and CW treatments, the percentage of heifers with an RTS of 5 (i.e., cycling) by May were 65,57 , and $59 \%$, respectively $(P=0.24)$. No differences were observed across treatments for uterine horn diameter, total follicle count, ovary length, or ovary height $(P \geq 0.43)$. Hip height and BCS were also not different across treatments $(P \geq 0.09)$. Pregnancy rates in August were greater in CC heifers (75.4\%) compared to CW heifers (64.3\%) but were not different from $C D$ heifers $(69.5 \% ; P=0.03)$.

\section{Conclusions}

Despite different rates of gain throughout the treatment period, all groups were similar in reproductive maturity by breeding. Therefore, it is concluded that plane of nutrition of heifers from 7 to 10 months of age may have an effect on reproductive success at the time of breeding. Achieving greater rates of gain with oat-brassica cover crop grazing from 7 to 9 months of age followed by corn residue grazing with DDGS supplementation for lower rates of gain could potentially be an effective method for developing beef heifers.

Hannah F. Speer, graduate student

Hannah E. Riley, graduate student

Robert A. Cushman and Harvey C. Freetly, U.S. Meat Animal Research Center, Clay Center, NE

Mary E. Drewnoski, associate professor, Animal Science, University of NebraskaLincoln 